\title{
Mead Production Using Immobilized Cells of Sacharomyces cerevisiae: Reuse of Sodium Alginate Beads
}

\author{
Miguel L. Sousa-Dias, Vanessa Branco Paula, Luís G. Dias $\mathbb{D}$ and Letícia M. Estevinho * \\ Centro de Investigação de Montanha (CIMO), Instituto Politécnico de Bragança, Campus de Santa Apolónia, \\ 5300-253 Bragança, Portugal; miglsdias@gmail.com (M.L.S.-D.); vanessapaula@ipb.pt (V.B.P.); \\ ldias@ipb.pt (L.G.D.) \\ * Correspondence: leticia@ipb.pt; Tel.: +351-273303342
}

Citation: Sousa-Dias, M.L.; Paula, V.B.; Dias, L.G.; Estevinho, L.M. Mead Production Using Immobilized Cells of Saccharomyces cerevisiae: Reuse of Sodium Alginate Beads. Processes 2021, 9, 724. https://doi.org/ $10.3390 /$ pr9040724

Academic Editor: Gema Pereira Caro

Received: 7 March 2021

Accepted: 12 April 2021

Published: 20 April 2021

Publisher's Note: MDPI stays neutral with regard to jurisdictional claims in published maps and institutional affiliations.

Copyright: (c) 2021 by the authors. Licensee MDPI, Basel, Switzerland. This article is an open access article distributed under the terms and conditions of the Creative Commons Attribution (CC BY) license (https:// creativecommons.org/licenses/by/ $4.0 /)$.
Abstract: This work studied the production of mead using second category honey and the immobilized cells of Saccharomyces cerevisiae in sodium alginate, with concentrations of $2 \%$ and $4 \%$, and their reuse in five successive fermentations. The immobilized cells with $4 \%$ alginate beads were mechanically more stable and able to allow a greater number of reuses, making the process more economical. The fermentation's consumption of sugars with free cells (control) and immobilized cells showed a similar profile, being completed close to $72 \mathrm{~h}$, while the first use of immobilized cells finished at $96 \mathrm{~h}$. The immobilized cells did not significantly influence some oenological parameters, such as the yield of the consumed sugars/ethanol, the alcohol content, the $\mathrm{pH}$ and the total acidity. There was a slight increase in the volatile acidity and a decrease in the production of $\mathrm{SO}_{2}$. The alginate concentrations did not significantly influence either the parameters used to monitor the fermentation process or the characteristics of the mead. Mead fermentations with immobilized cells showed the release of cells into the wort due to the disintegration of the beads, indicating that the matrix used for the yeast's immobilization should be optimized, considering the mead production medium.

Keywords: honey; mead; Sacharomyces cerevisiae; free cells; immobilization of cells; sodium alginate

\section{Introduction}

Mead is a traditional alcoholic drink, which contains between 8 and $18 \%(v / v)$ ethanol; it originates from diluted honey fermentation by yeast [1]. Mead's capability to partake in the fermenting process depends fundamentally on the honey's variety, yeast strain, the composition of the culture media and the $\mathrm{pH}$ [2]. In accordance with Pereira et al. [3], the most adequate yeast strain is ICV D47, as it presents a high rate of fermentation, low production of acetaldehyde and volatile acidity and high resistance to $\mathrm{SO}_{2}$.

For the production of mead, the first step involves diluting the honey along with a mixture of nutrients that will provide the essential nutrients for the growth of yeasts that are deficient in the honey. In this mixture, there can be included $\left(\mathrm{NH}_{4}\right)_{2} \mathrm{SO}_{4}, \mathrm{CaSO}_{4}$, $\left(\mathrm{NH}_{4}\right)_{3} \mathrm{PO}_{4}, \mathrm{NH}_{4} \mathrm{H}_{2} \mathrm{PO}_{4},\left(\mathrm{NH}_{4}\right)_{2} \mathrm{HPO}_{4} \mathrm{DAP}, \mathrm{K}_{3} \mathrm{PO}_{4}, \mathrm{MgCl}_{2}, \mathrm{MgSO}_{4} \cdot 7 \mathrm{H}_{2} \mathrm{O}, \mathrm{NaHSO}$, citric acid, sodium citrate, tartaric acid, potassium tartrate, sodium and potassium tartrate, malic acid, vitamins, myo-inositol, peptone, or commercial yeast [2,4-6]. According to the study of Roldán et al. [7], the addition of pollen in the wort improves the rate of fermentation, the production of alcohol and the sensory attributes of the mead. Another step is to reduce the microbial load present in the medium so as not to interfere with the fermentation processes. The wort can be sterilized later, the sterilization method being the most used $[2,4,8]$. However, these heat treatments alter the phenolic profiles by changing their antioxidant properties [9]. The literature mentions other less aggressive techniques to reduce the microbial load, which include the use of meta bisulfite salts that release sulfur dioxide that eliminates or inhibits most microorganisms [4,7]; sulfur dioxide gas [5,8], pasteurization [6], and ultrafiltration are other methods used [4]. After this step, the $\mathrm{pH}$ should be adjusted to a range of 3.7 to 4.0 with the addition of a buffer [4]. Calcium carbonate, potassium 
carbonate, potassium bicarbonate, tartaric acid are possible buffers used to adjust the $\mathrm{pH}$. However, the increase in these salts can lead to the development of flavors, such as bitter and salty [4]. Despite the buffer solution, the $\mathrm{pH}$ drops during fermentation which can decrease the efficiency of the yeast, leading to the production of acetic and succinic acid [1] and contributing to the fermentation's deceleration or pouting [7]. Usually, fermentation is carried out at room temperature according to McConnell et al. [4]. However, there are several works using different temperatures: Navrátil et al. [2] used temperatures at 25, 30, 35 and $40{ }^{\circ} \mathrm{C}$; Ukpabi [8], at 25 and $26{ }^{\circ} \mathrm{C}$; Pereira et al. [5], at $27^{\circ} \mathrm{C}$; and MendesFerreira et al. [6], at temperature of $22^{\circ} \mathrm{C}$.

Overall, the characteristics of honey and the supplements used in the wort's composition affect the mead production: dark honey is richer in minerals and the $\mathrm{pH}$ is higher than light honey, making it a better raw material [5]; relatively high amounts of chain fatty acids are believed to inhibit fermentation [1]; the addition of tartaric acid helps to prevent pouting from fermentation [6]; and minimum nitrogen requirements (level of nitrogen in the solution modifies the mead at the sensory level, leading to the production of volatile aromatic compounds [7]) are linked to the yeast growth rate and ethanol concentration [10]. In addition, the production of a stable and high-quality mead requires fermentation monitoring to ensure that it is possible to achieve the desired alcohol content and to avoid secondary fermentations [11], which is also dependent on the selected microorganism, as well as its application procedure (free or immobilized cells).

In recent years, cell immobilization systems have been explored to carry out alcoholic fermentations in order to reduce operating costs, control fermentation processes and increase the quality of the final product $[12,13]$. Immobilized microorganisms allow for increased productivity, the synthesis of metabolites and increases the efficiency of fermentation, due to the high concentration of cells $[14,15]$. Other advantages are also referred to, such as the possible reuse of biomasses in consecutive batch processes, greater tolerance to inhibitory substances and elimination of contamination, decreased formation of by-products, decreased costs for the process, cost reduction with centrifugation, and filtration and purification of the final product $[12,13,16]$. However, one of the biggest advantages is the reuse, especially when the supports chosen for immobilization are inert and have high mechanical resistance.

Alginate has been the most studied natural polymer for immobilizing viable cells due to its biocompatibility [17]. Sodium alginate is a natural polysaccharide, derived mainly from brown seaweed $[16,18]$. This polysaccharide is generally less affected by microbial attack than other carbohydrates [16]. It is a biocompatible, biodegradable compound without toxicity, presenting gelling capacity [16,19]. According to Carvalho [20], alginate gelation occurs quickly without drastic changes in temperature, $\mathrm{pH}$ and osmotic pressure, thus allowing the viability of the immobilized microorganism to be preserved. Alginate is a cheap and easily found material, which can be prepared in large quantities in an easy and quick way $[20,21]$.

The encapsulation of microorganisms can be done by two procedures: microorganisms present in a natural polymer solution are added by dripping into a solution of calcium ions (calcium chloride), forming a consistent and insoluble gel (procedure used in this work), due to ionic bonds [16,22,23]; microorganisms in a calcium chloride solution are added dropwise to the natural polymer solution and the capsule forms [23]. The size of the beads will depend on the flow rate, the density of the polymer solution and the concentration of the calcium solution [23] and, in general, have a diameter ranging from $0.2 \mathrm{~mm}$ to $2 \mathrm{~mm}$ [22]. Several works show the advantages of the application of immobilized cells on alginate in alcoholic fermentation studies. Nikolić et al. [24] studied the fermentation of ethanol in corn with yeast immobilized in calcium alginate, obtaining a greater tolerance to ethanol and no inhibition of the product with immobilized cells. Vilela et al. [25] studied the S26 cells in double layer chitosan-alginate beads in order to reduce the volatile acidity of a wine, managing to reduce the acidity from 28 to $62 \%$ in 72 and $168 \mathrm{~h}$, respectively, with a decrease in ethanol (0.7\%). Ciani and Ferraro [26] with Schizosaccharomyces pombe cells 
encapsulated in calcium alginate beads showed that possible to reduce the fixed acidity of the wine by degrading the malic acid.

However, all these advantages depend on the stability of the immobilization matrix. The immobilization matrix must be inert, insoluble, non-biodegradable and mechanically stable during the different operations in a bioreactor. Mechanical stability depends in particular on the viscoelastic properties and the concentration of the sodium alginate solution, which may be significantly affected by the yeast [27].

The most common problem that occurs during alcoholic fermentation with immobilized cells is the release of cells from the inside of the beads to the outside, due to the destabilization of the gel. This rupture occurs due to cell growth, the formation and accumulation of $\mathrm{CO}_{2}[19,25,28]$, the presence of non-gelling ions, namely $\mathrm{Mg}, \mathrm{Na}$ or $\mathrm{K}$, and the presence of chelating agents (lactate, citrate or phosphate) $[25,28]$. The $\mathrm{O}_{2}$ distribution is important because non-uniform aeration can cause cells to migrate into the environment, leading to the breakdown of the gel [15].

This work aims to evaluate the effect of Saccharomyces cerevisiae cells immobilized on sodium alginate in the mead fermentation, the reuse efficiency of immobilized cells and, in parallel, the influence of the alginate concentration on fermentation efficiency.

\section{Materials and Methods}

\subsection{Honey Sample}

For the production of mead, dark second category honey was used (from the region of Trás-os-Montes, Portugal); in other words, honey that doesn't hold the protected designation of origin and is used for feeding bees. The honey quality was evaluated through the determination of some parameters, established in the Portuguese legislation for regulating honey production (Decree-Law $\mathrm{N}^{\circ}$ 214/2003, 18 September), using analytical methods approved by Codex Alimentarius: humidity, electric conductivity, total ash, $\mathrm{pH}$, acidity, hydroxymethilfurfural, diastatic index, reducing sugars and apparent sucrose. The honey was also evaluated in its pollinic spectrum to identify its floral origin. These analyses were carried out in triplicate.

\subsection{Honeys Quality}

The water content of the honey was determined using the refractometric method according to the Harmonized Methods of the International Honey Commission (IHC) (2002) [29]. The electrical conductivity of the honey was determined by the method described by Sancho et al. [30]. The ash content of the honey was determined using the conductivity value, according to the methodology described by Sancho et al. [30]. The $\mathrm{pH}$ of the honey was determined according to the method described by Bogdanov et al. [31]. The acidity of the honey was determined in accordance with the method proposed by Bogdanov et al. [31]. The hydroxymethylfurfural (HMF) content of the honey was determined according to the method described by IHC [29]. The diastatic index of the honey was determined based on the method proposed by Anónimo [32]. The content of reducing sugars (glucose and fructose) in the honey was determined according to the method described by Bogdanov et al. [31]. The apparent sucrose content of the honey was determined by the inversion method according to Bianchi [33]. The content of inverted sugar before inversion corresponds to the content of reducing sugars in the honey.

\subsection{Pollen Analysis}

The pollen analysis of the honey was determined by the method described by Louveaux et. al. [34]. The different types of pollen present in the sample were identified and quantified (count at minimum 1000 grains of pollen).

\subsection{Mead Production}

To evaluate the effect of reusing immobilized cells on mead production, the commercial yeast Saccharomyces cerevisiae ICV D47 was used. This yeast was selected considering 
the results obtained by Pereira et al. [3] and its oenological characteristics. Yeast was immobilized in 2 and $4 \%$ of sodium alginate and the beads were reused in five successive mead fermentations. As the control, a fermentation was carried out under the same conditions and with the same strain, but in the free form.

\subsubsection{Preparation of Honey Must}

To obtain an alcoholic drink with a percentage of approximately $12 \%$ ethanol, the honey was dissolved in bottled commercial water at a rate of $314 \mathrm{~g}$ per $1 \mathrm{~L}$. The honeywater mixture was supplemented with commercial nutrients (Enovit, $60 \mathrm{~g} / \mathrm{hL}$ ) and, after homogenization of the mixture, the $\mathrm{pH}$ was adjusted to 3.8 with tartaric acid (SigmaAdrich, St. Louis, MI, USA). The honey must was pasteurized at $70{ }^{\circ} \mathrm{C}$ for $30 \mathrm{~min}$ and immediately cooled. To characterize the honey must before fermentation, the physicalchemical parameters ${ }^{\circ}$ Brix, $\mathrm{pH}$, assimilable nitrogen, total acidity and reducing sugars were determined.

\subsubsection{Yeast Hydration and Immobilization}

The commercial oenological yeast selected for the production of mead was Saccharomyces cerevisiae Lalvin ICV D47 (Lallemand, Montreal, QC, Canada). According to the instructions in the technical sheet, the dry active yeast $(30 \mathrm{~g} / \mathrm{hL})$ was hydrated in the proportion of $1 \mathrm{~kg}$ of yeast to $10 \mathrm{~L}$ of sterile water. The suspension was placed in a water bath at $37^{\circ} \mathrm{C}$ for $15 \mathrm{~min}$ and then stirred a few times for $20 \mathrm{~min}$. The hydration time did not exceed $40 \mathrm{~min}$. For yeast immobilization, concentrations of 2 and $4 \%(w / v)$ of sodium alginate (BDH Prolabo, Leuveu, Belgium) were used. The sodium alginate was dissolved in distilled water and autoclaved at $121^{\circ} \mathrm{C}$ for $15 \mathrm{~min}$. The yeast, after hydration, was added to the respective alginate solutions. For the formation of the beads, the polymer-cell mixture was poured into a syringe and allowed to drip into a sterile $0.18 \mathrm{M} \mathrm{CaCl}_{2}$ solution (Panreac, Barcelona, Spain), with stirring. The beads were left in this solution for $30 \mathrm{~min}$ at $4{ }^{\circ} \mathrm{C}$, to harden. Before inoculation, the beads were washed three times with sterile distilled water.

\subsubsection{Conditions and Monitoring of Fermentation}

The volume of $300 \mathrm{~mL}$ of honey must was distributed in $500 \mathrm{~mL}$ conical flasks, previously sterilized, and inoculated with the yeast in a free or immobilized form. The fermentations took place at $25^{\circ} \mathrm{C}$, in an incubator (TH 25 Edmund Bühler 3019) with agitation of $120 \mathrm{rpm}$. The fermentation was monitored daily through quantification of the following parameters: reducing sugars, cell biomass and cell viability. Cellular biomass was evaluated by measuring the optical density at $640 \mathrm{~nm}$ on a UV-Vis spectrophotometer (UV-Vis Unicam He入ios spectrophotometer). When necessary, the samples were diluted with honey must, which was also used as blank solution. The specific growth rates $(\mu)$ were calculated from the slope of the linear relationship between the values of the optical density, at $640 \mathrm{~nm}$, and the fermentation time, according to the equation: $\ln \left(\mathrm{N}_{\mathrm{t}}\right)=\ln \left(\mathrm{N}_{0}\right)$ $+\mu_{t}$, where $\mu$ corresponds to the specific growth rate, expressed in units of the inverse of time $\left(\mathrm{h}^{-1}\right)$, and $\mathrm{N}_{\mathrm{t}}$ and $\mathrm{N}_{0}$ to the population density, expressed by the OD at $640 \mathrm{~nm}$, at the end of time $t$ and $t_{0}$, respectively. The cell viability was determined by quantifying the colony-forming units (UFC's) in the yeast peptone dextrose solid medium (YPD$20 \mathrm{~g} / \mathrm{L}$ glucose, $10 \mathrm{~g} / \mathrm{L}$ peptone, $5 \mathrm{~g} / \mathrm{L}$ yeast extract and $20 \mathrm{~g} / \mathrm{L}$ agar). When necessary, dilutions were made, and the plates were incubated at $25{ }^{\circ} \mathrm{C}$ for $3-5$ days. Reducing sugars were quantified by the DNS method (3,5-dinitrosalicylic acid) according to the procedure proposed by Miller [35], using glucose as a standard. In a test tube, $500 \mu \mathrm{L}$ of the centrifuged sample and $500 \mu \mathrm{L}$ of the DNS reagent were added. The tubes were placed for $5 \mathrm{~min}$ in a thermostatic bath at $100{ }^{\circ} \mathrm{C}$, after which they were cooled to room temperature. Then, $5 \mathrm{~mL}$ of distilled water was added and, after stirring the mixture, the absorbance was read on a UV-Vis spectrophotometer (Varian Cary 50 Scan model UV-Vis spectrophotometer) at $540 \mathrm{~nm}$. A test was prepared with distilled water to perform the 
zero adjustment of the spectrophotometer. When necessary, dilutions of the sample were made with distilled water. The results of reducing sugars were expressed in $\mathrm{g} / \mathrm{L}$. At the end of the alcoholic fermentation, the mead obtained was clarified by centrifugation to assess its physical-chemical characteristics through several oenological parameters.

\subsection{Physical-Chemical Characterization of Honey Must and Mead}

To determine the characteristics of the honey must before fermentation and to evaluate the quality of the produced mead, several physical-chemical analyses were carried out in triplicate at the beginning and end of the fermentations. To characterize the honey must, $\mathrm{pH},{ }^{\circ}$ Brix, total acidity and assimilable nitrogen were determined. At the end of the fermentations, the produced meads were evaluated for $\mathrm{pH}$, total sulfur dioxide $\left(\mathrm{SO}_{2}\right)$, total acidity, volatile acidity, assimilable nitrogen and alcohol content. The ethanol yield of each fermentation was also determined.

The $\mathrm{pH}$ of the honey must and mead was determined by direct reading using a $\mathrm{pH}$ meter (pHMeter Basic 20), as referred to by the Organisation International de la Vigne e $\mathrm{du}$ Vin (OIV) [36]. The total acidity of the honey must and mead were determined based on the method proposed by the OIV [36]. The assimilable nitrogen was determined in the must-honey solution and in the mead by the formaldehyde method according to the methodology described by Aerny [37]. ${ }^{\circ}$ Brix was determined by refractometry in the honey must using a portable refractometer (Zuzi serie 300) [36]. The determination of the total mead $\mathrm{SO}_{2}$ was carried out according to the Ripper methodology described by the OIV [38] as a quick method. The determination is based on direct iodometric titration in an acid medium [39]. The volatile acidity of the mead was determined by the method described by the OIV [36], which consists of the titration of volatile acids that were obtained by distillation using the Cazenave-Ferré apparatus. The alcoholic strength of the mead was determined by boiling, the usual method of the OIV [36]. In the production of mead, the yields of fermentation in ethanol were calculated according to the following equation: yield ethanol $(\%)=$ consumed sugars $(\mathrm{g} / \mathrm{L}) /$ ethanol produced $\times 100$.

\subsection{Characterization of Alginate Beads at the End of Fermentation}

At the end of the fifth reuse, to determine the concentration of viable cells in the beads with 2 and 4\% sodium alginate, the beads were liquefied using a chemical method, according to the procedure adapted from Göksungur et al. [40]. The 50 beads were weighed and dissolved in $50 \mathrm{~mL}$ of a sterile $50 \mathrm{mM}$ sodium citrate solution (Merck, Darmstadt, Germany), with continuous stirring for approximately $1 \mathrm{~h}$ at room temperature. The cell viability was determined by quantifying CFU's in the YPD medium, incubated at $25{ }^{\circ} \mathrm{C}$, for 3-5 days.

\subsection{Statistic Treatment}

The statistical analysis of the data was performed using the SPSS program (Statistical Package for Social Sciences) version 17.0. Compliance with the ANOVA requirement, namely the homogeneity of variance, was assessed using the Levene test. All dependent variables (analytical parameters) were analyzed using one-way ANOVA using, as the factor, the type of fermentation performed (free cells or immobilized cells with $2 \%$ or $4 \%$ alginate and their number of uses); when significant differences were found, the means were compared using the Tukey test, a multiple comparison test. All statistical tests were performed to a significance level of 5\% using, as the factor, the type of fermentation performed (free cells or immobilized cells with $2 \%$ or $4 \%$ alginate and their number of uses).

\section{Results and Discussion}

\subsection{Pollen Analysis of Honey}

To determine the botanical origin of the honey, its polinic spectrum was analyzed. The counting of the pollen present in the honey was carried out by microscopy, as described in the Material and Methods section. The five pollen most prevalent were, in descending order, 
Castanea sp. (73.47\%); Erica sp. (12.24\%); Echium sp. (6.12\%); Trifolium sp. (5.11\%); and Prumus sp. (3.06\%). This profile is common in the dark honey of Trás-os-Montes (Portugal), and allows classifying the honey monofloral of Castanea sativa (73.47\%) according to the classification of Maia [41].

\subsection{Physical-Chemical Characterization of the Honey}

For the production of mead, second category dark honey, coming from the region of Trásos-Montes, was used, which was analyzed according to the Portuguese legislation Decree-Law $N^{\circ} 214 / 2003$ (18 September), in order to evaluate its quality. These analyses should be made of all the types of honey used in the production of mead, because the quality of this alcoholic drink depends on the characteristics of the raw material used in its production.

In Table 1, the average results (with the respective standard deviations) of the physicalchemical analysis are shown. The precision of the analyzed parameters was acceptable; in general, the percentage relative to the standard deviation was less than $3.5 \%$, with the exception of the HMF analysis which presented a value of $12 \%$. These parameters are found inside the values established in the Portuguese Decree-Law N ${ }^{\circ}$ 214/2003 (18 September), with the exception of apparent sucrose which, in this case, was obtained at $8.39 \mathrm{~g} / 100 \mathrm{~g}$ of honey while, generally, the maximum should be $5 \mathrm{~g} / 100 \mathrm{~g}$ of honey.

Table 1. Honey's physical-chemical results.

\begin{tabular}{cc}
\hline Parameter & Honey \\
\hline Humidity (\%) & $17.2 \pm 0.2$ \\
Acidity (meq. Ac/Kg) & $16.0 \pm 0.7$ \\
Electrical Conductivity (mS/cm) & $0.80 \pm 0.01$ \\
Total Ash (\%) & $0.56 \pm 0.02$ \\
pH & $4.47 \pm 0.06$ \\
Diastatic Index (Schade scale) & $13.3 \pm 0.5$ \\
HMF (mg/Kg) & $8.3 \pm 1.0$ \\
Reducing sugars (\%) & $62.4 \pm 0.6$ \\
Apparent Sucrose (\%) & $8.9 \pm 0.3$ \\
\hline
\end{tabular}

The honey used in this work had $17.2 \%$ moisture, which is less than the $20 \%$ stipulated in the Portuguese legislation, suggesting that the honey was extracted, processed and stored according to good manufacturing practices. The water content of honey is an important parameter in quality, as it allows to predict the product's duration and its ability to remain stable [42]. The higher the water content, the more likely the honey is to ferment during storage, leading to its deterioration, a loss of flavor, and, consequently, a reduction in shelf life [43-45]. Despite this, if the production of mead is done in a timely manner and under the appropriate hygiene conditions, as mead results from the mixture of honey with water, this parameter is not the one that most significantly affects the quality of this product.

Portuguese legislation requires that quality honey must contain less than 50 milliequivalents of acids per $1000 \mathrm{~g}$ of honey; in this work, the analyzed honey presented a much lower value ( 16.0 milliequivalents of acids per $1000 \mathrm{~g}$ of honey). The free acidity depends on the floral origin of the honey and is due to the presence of organic acids, resulting either from the degradation of glucose by the action of the glucose oxidase enzyme with the production of gluconic acid (the action of this enzyme is maintained even during storage), or the action of bacteria during the maturation of the honey. Thus, this parameter is an indicator of the occurrence of fermentation in the honey [46-49].

The honey studied had a $\mathrm{pH}$ value of 4.47 which is within the expected range since, according to Iurlina et al. [50], the $\mathrm{pH}$ of honey varies between 3.4 and 6.1, with an average of 3.9. The $\mathrm{pH}$ is not currently included in the mandatory analysis of honey quality control. However, the $\mathrm{pH}$ of honey is very important because it influences the development of microorganisms, in addition to conditioning the speed of the HMF formation [51]. It should 
also be noted that to produce mead, the $\mathrm{pH}$ of the honey-water mixture should be around 3.5 , and it is often necessary to use tartaric acid to correct the value of this parameter.

The electrical conductivity value obtained was $0.80 \mathrm{mS} / \mathrm{cm}$, which is an expected value for a Castanea sativa monofloral honey, as confirmed by the pollen spectrum. According to Portuguese Decree-Law N ${ }^{\circ}$ 214/2003 (18 September) about honeydew honey, the honey from the chestnut flower and mixtures of these honeys must contain at least $0.8 \mathrm{mS} / \mathrm{cm}$, while the other honeys not listed in the Portuguese Decree-Law should be less than $0.8 \mathrm{mS} / \mathrm{cm}$. The electrical conductivity can be used to determine the botanical origin of honey.

The total ash value of $0.56 \%$ obtained in this work indicates a high percentage of salts, contrasting with the values obtained by Rodríguez [43] ( 0.19 to 0.4 ) in honeys produced in Venezuela. According to Al et al. [45], the ash content expresses the content of minerals present in the honey and is the factor that most influences the color of the honey. The higher the mineral content, the darker the color of the honey will be. Its content is related to the botanical origin, environment and conditions of production and processing. In the Portuguese Decree-Law, there are no specifications regarding the ash content present in honey, but the Brazilian legislation determines a maximum content of $0.6 \%$ for floral honeys and $1.2 \%$ for honeydew honeys and their mixture with floral honeys.

Portuguese Decree-Law N ${ }^{\circ}$ 214/2003 (18 September) indicates, for diastatic activity, a minimum of 0.8 in the Schade scale and for HMF, a maximum of $40 \mathrm{mg} / \mathrm{kg}$. The studied honey presented 13.3 of the diastatic index and $8.3 \mathrm{mg} / \mathrm{Kg}$ of HMF, indicating that during the processing, good manufacturing practices were respected since the honey is young and has not been tampered with. Diastasis is a group of enzymes ( $\alpha$ - and $\beta$-amylases) secreted by the bee that hydrolyze starch, resulting in dextrin and maltose, respectively. This enzyme is sensitive, so its analysis is used to evaluate whether the honey suffered overheating during the processing and storage of the honey [44], or adulteration [52]. So, diastatic activity is a freshness index of honey, but it must be interpreted together with the HMF content [53]. The diastatic index decreases with time of storage, or abuse of temperature $[44,54]$. HMF is a compound formed by the dehydration of hexoses in acidic conditions and its formation kinetics varies directly with temperature, thus decreasing the nutritional value of the product. The presence of HMF directly influences the color, flavor and odor; therefore, it is used as a parameter of honey quality [53]. Honey normally has small concentrations of HMF in its constitution; that is why higher concentrations indicate overheating, prolonged storage and adulteration [44].

Reducing sugars and apparent sucrose had values of $62.4 \%$ and $8.9 \%$, respectively. Nectar honey should have a minimum glucose and fructose value of $60 \mathrm{~g} / 100 \mathrm{~g}$ (DecreeLaw $\mathrm{N}^{\circ}$ 214/2003, 18 September). Glucose and fructose are the main reducing sugars present in honey [47]. The analyzed honey fulfills this requirement. The concentration of sucrose allows to differentiate between monofloral and multifloral honeys [55], indicating high levels of premature collection, that is, the sucrose has not yet been converted into fructose and glucose [56]. Regarding the apparent sucrose parameter, the Portuguese Decree-Law establishes, for monofloral honeys of Robinia pseudoacacia (false acacia), Medicago sativa (lucerne or alfalfa), Banksia menziesii (Mensies Banksia), Hedysarum (hedisaro), Eucalyptus camadulensis, Eucryphia lucida, Eucryphia milligpanii, and Citrus (citrus) spp., the maximum limit of $10 \mathrm{~g} / 100 \mathrm{~g}$; for honeys of Lavandula (rosemary, lavender) and Borago officinalis (borage) spp., the maximum limit of $15 \mathrm{~g} / 100 \mathrm{~g}$; and for all other honeys, the maximum limit of $5 \mathrm{~g} / 100 \mathrm{~g}$.

In summary, the honey used for the production of mead, according to the parameters analyzed, is a good quality honey, despite being a second category honey.

\subsection{Mead Production Using Immobilized Cells in Alginate Beads}

In this work, two concentrations of alginate were used to check the influence of the mechanical stability of the beads in the production of mead. In fact, stability depends not only on the viscoelastic properties and the concentration of the sodium alginate solution, but 
also on the number of immobilized cells [27]. To identify possible changes in the structure of the beads during reuse, these were analyzed visually immediately after immobilization and at the end of reuse (Figure 1). The beads of both concentrations of the alginate showed structural changes at the end, which were more evident in the beads with $2 \%$ alginate because most of them were deformed and open. In the case of beads with a concentration of $4 \%$ alginate, after five fermentations, the beads showed only small cracks on their surface. These results showed that the $4 \%$ alginate beads are mechanically more stable, allowing a greater number of reuses, thus making the process more economical. After the five fermentations, it was found that those with $2 \%$ alginate contained $4.65 \times 10^{8} \mathrm{CFU} / \mathrm{g}$ beads, while the $4 \%$ beads contained $1.98 \times 10^{8} \mathrm{CFU} / \mathrm{g}$ beads; that is, the alginate concentration did not influence the number of viable cells inside the beads.

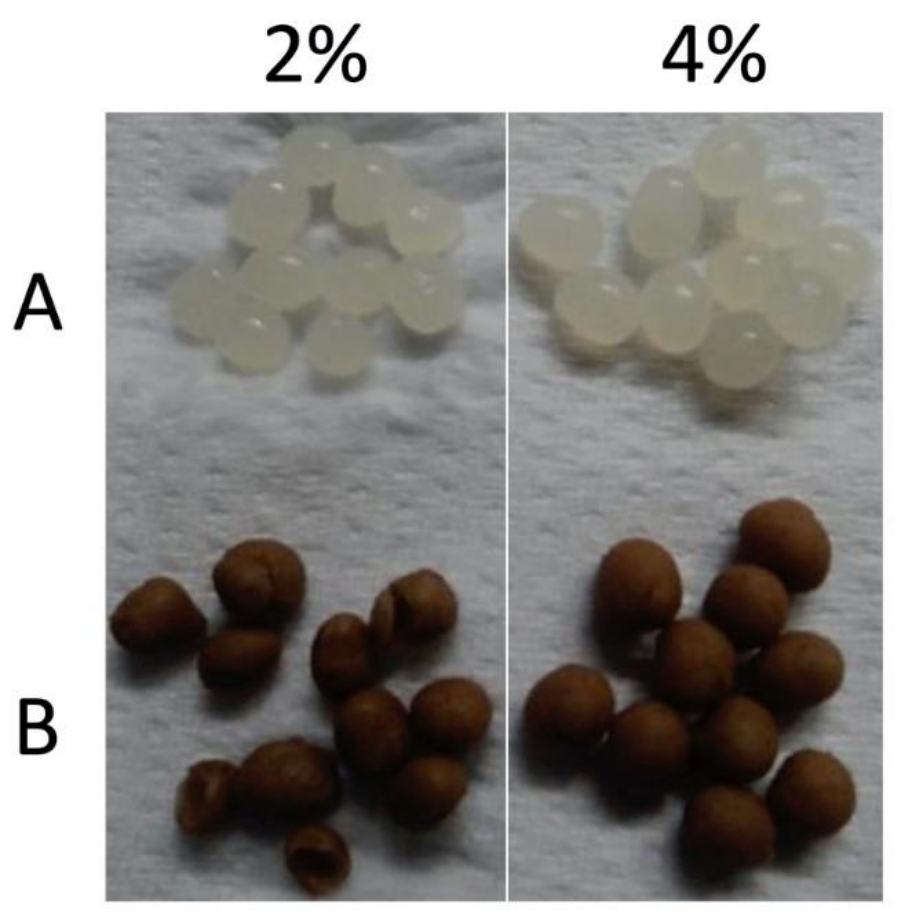

Figure 1. Immobilized S. cerevisiae in $2 \%$ and $4 \%$ sodium alginate beads: (A)—start of the immobilization process; (B)—after five reuses.

\subsection{Fermentation Performance during Reuse of Immobilized Cells}

The wort used in the different fermentations was prepared in order to obtain, at the end of the fermentation, an alcohol content of $12 \%$, as described in the Material and Methods section. After each wort preparation, the physical-chemical characteristics were determined, and the results are shown in Table 2.

Table 2. Physical-chemical analysis of honey must.

\begin{tabular}{|c|c|c|c|c|c|c|}
\hline \multicolumn{2}{|c|}{ Fermentation } & \multirow{2}{*}{$\mathrm{pH}$} & \multirow{2}{*}{${ }^{\circ}$ Brix } & \multirow{2}{*}{$\begin{array}{c}\text { Total Acidity } \\
\text { (g/L Tartaric Acid) }\end{array}$} & \multirow{2}{*}{$\begin{array}{c}\text { Assimilable Nitrogen } \\
(\mathrm{mg} / \mathrm{L})\end{array}$} & \multirow{2}{*}{$\frac{\text { Reducing Sugars }}{(\mathrm{g} / \mathrm{L})}$} \\
\hline Type & $\mathbf{N}^{\circ}$ & & & & & \\
\hline Free cells & & $3.71 \pm 0.06$ & $23.0 \pm 0.1$ & $1.33 \pm 0.09$ & $254 \pm 7$ & $221 \pm 17$ \\
\hline \multirow{5}{*}{$\begin{array}{l}\text { Immobilized } \\
\text { cells }\end{array}$} & $1 \mathrm{st}$ & $3.83 \pm 0.06$ & $24.5 \pm 0.1$ & $1.58 \pm 0.01$ & $212 \pm 11$ & $274 \pm 23$ \\
\hline & 2nd & $3.82 \pm 0.09$ & $24.3 \pm 0.1$ & $1.55 \pm 0.04$ & $238 \pm 7$ & $246 \pm 9$ \\
\hline & $3 \mathrm{rd}$ & $3.83 \pm 0.04$ & $23.5 \pm 0.1$ & $1.25 \pm 0.04$ & $243 \pm 4$ & $252 \pm 22$ \\
\hline & 4 th & $3.83 \pm 0.06$ & $24.4 \pm 0.2$ & $1.4 \pm 0.1$ & $259 \pm 1$ & $230 \pm 8$ \\
\hline & 5 th & $3.83 \pm 0.04$ & $24.5 \pm 0.1$ & $1.45 \pm 0.04$ & $289 \pm 18$ & $245 \pm 10$ \\
\hline
\end{tabular}


In this work, five independent repetitions were performed but, despite all efforts to try to obtain a uniform must for all fermentations, small variations were observed in almost all the parameters analyzed, as shown in Table 2. This may be due mainly to the small variability in the composition of the must made from honey and the added nutrients, as well as, to a lesser extent, the type of inoculum (free or immobilized), the initial inoculum concentration and the growth behavior of the yeasts. The differences that occurred between the musts used in the fermentation with free cells and those used in fermentations with immobilized cells were considered a random variability because the experimental design considered similar musts for all fermentations.

The most common problem that can occur during alcoholic fermentation using yeast cells immobilized in alginate beads is the release of cells from inside the beads into the fermentation medium, due to the breakdown of the gel. Bead ruptures may occur due to cell growth, $\mathrm{CO}_{2}$ formation and accumulation $[19,25,28]$, the presence of chelating agents and the presence of non-gelling ions, namely $\mathrm{Mg}^{2+}$ or $\mathrm{K}^{+}$, which replace the sodium ions in the alginate gel $[27,28,57]$. From the analysis of Figure 2, it was found that in all fermentations using cells immobilized with $2 \%$ and $4 \%$ alginate, cells were released from the beads into the must. Although the $4 \%$ alginate beads are mechanically more resistant and show fewer changes after being used give times, they did not prevent the cells from leaving the medium. In the first use of the $2 \%$ and $4 \%$ alginate beads, cells were detected in the fermentation medium $24 \mathrm{~h}$ after the start, while in the second reuse, and in the subsequent reuse, the presence of cells was observed at zero time. These results indicate that the must, prepared based on honey, interferes with the stability of the alginate beads right in the first fermentation, and that the integrity of the beads gradually deteriorates in the following fermentations.
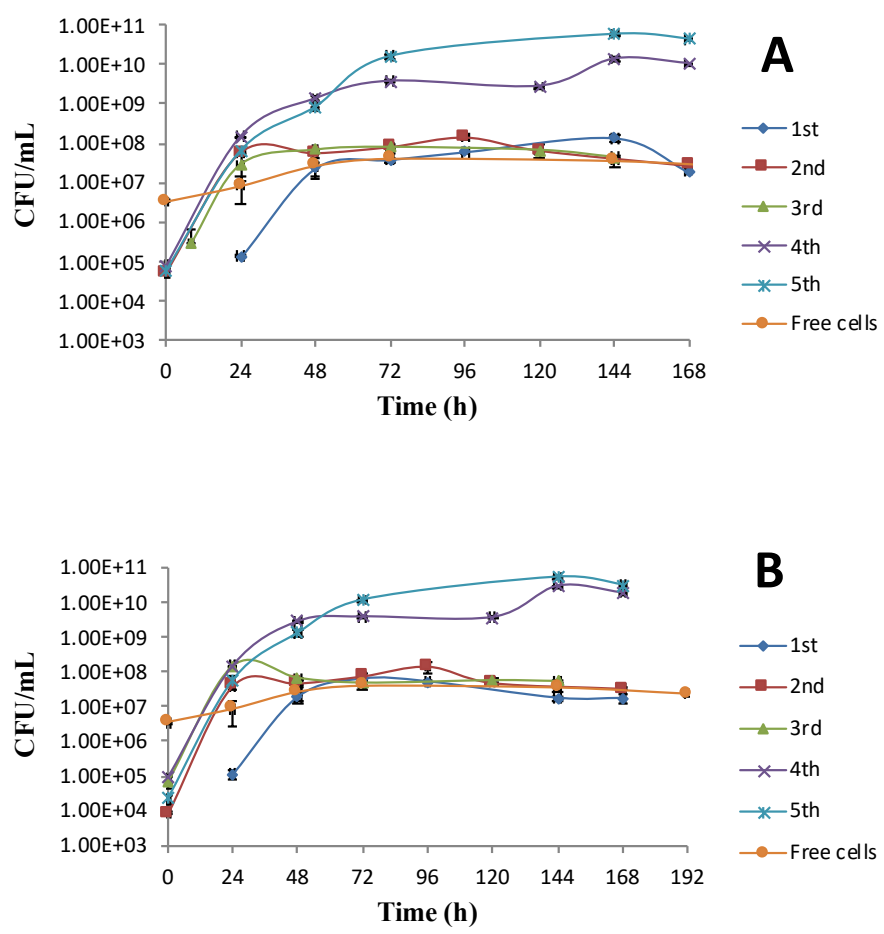

Figure 2. Fermentations with S. cerevisiae free cells and immobilized cells as a function of time: (A) - beads of $2 \%$ alginate reused in five fermentations; (B)-beads of $4 \%$ alginate reused in five fermentations.

According to Mendes-Faia et al. [58], the changes in the integrity of the beads must be visualized during the first fermentation and subsequent fermentations, and not just at the end of the process. Vilela et al. [25] reported that the integrity of the alginate-chitosan 
beads depends on the $\mathrm{pH}$ of the wort and for values of $\mathrm{pH}$ equal to or greater than 3.5 , the loss of integrity of the alginate-chitosan beads is expected.

In the future, it would be advisable to carry out additional studies using other materials for cell immobilization and to evaluate the $\mathrm{pH}$ and other must variables in the integrity of the beads.

In order to evaluate the stability of the beads with $2 \%$ and $4 \%$ alginate during successive reuses in the production of mead, the growth of free S. cerevisiae cells, that is, cells resulting from the rupture of the beads during fermentation, was quantified, by measuring biomass by spectrophotometry and cell viability. The final yield of each fermentation was evaluated by the amount of ethanol produced per gram of sugar consumed. These results (response variable) are presented in Table 3, as well as the results of the one-way ANOVA using, as the factor, the type of fermentation performed (free cells or immobilized cells with $2 \%$ or $4 \%$ alginate and their number of uses). It should be noted that the cell concentration within the beads was only determined at the end of the fifth fermentation.

Table 3. Specific growth rate, final free cell biomass and ethanol yield for the five different fermentations.

\begin{tabular}{|c|c|c|c|c|}
\hline \multicolumn{2}{|c|}{ Fermentation } & \multirow{2}{*}{$\frac{\mu \mathrm{c}}{\left(\mathrm{h}^{-1}\right)}$} & \multirow{2}{*}{$\frac{\text { BF }}{(\mathrm{CFU} / \mathrm{mL})}$} & \multirow{2}{*}{$\frac{Y_{\text {ethanol/sugars }}}{(\%)}$} \\
\hline Type & $\mathbf{N}^{\circ}$ & & & \\
\hline Free cells & Control & $0.15 \pm 0.006^{\mathrm{c}}$ & $2.4 \times 10^{7} \pm 5 \times 10^{6 a}$ & $58 \pm 4^{a}$ \\
\hline \multirow{5}{*}{$\begin{array}{l}\text { Immobilized cells with } \\
2 \% \text { alginate }\end{array}$} & 1 st & $0.11 \pm 0.04^{\mathrm{b}}$ & $1.8 \times 10^{7} \pm 2 \times 10^{6} a$ & $48 \pm 5^{a}$ \\
\hline & $2 \mathrm{nd}$ & $0.18 \pm 0.01$ def & $2.70 \times 10^{7} \pm 1 \times 10^{6 a}$ & $54.56 \pm 0.05^{\mathrm{a}}$ \\
\hline & $3 \mathrm{rd}$ & $0.19 \pm 0.0004^{\mathrm{fg}}$ & $4.45 \times 10^{7} \pm 7 \times 10^{5 a}$ & $55 \pm 1^{\mathrm{a}}$ \\
\hline & 4 th & $0.15 \pm 0.0002^{\mathrm{cd}}$ & $1.04 \times 10^{10} \pm 3 \times 10^{8 b}$ & $58 \pm 2^{a}$ \\
\hline & 5 th & $0.16 \pm 0.006^{\text {cde }}$ & $4.4 \times 10^{10} \pm 2 \times 10^{9} \mathrm{e}$ & $52.4 \pm 0.3^{\mathrm{a}}$ \\
\hline \multirow{5}{*}{$\begin{array}{c}\text { Immobilized cells with } \\
4 \% \text { alginate }\end{array}$} & $1 \mathrm{st}$ & $0.080 \pm 0.006^{\mathrm{a}}$ & $1.8 \times 10^{7} \pm 6 \times 10^{6 a}$ & $48 \pm 4^{\mathrm{a}}$ \\
\hline & 2 nd & $0.19 \pm 0.004^{\mathrm{fg}}$ & $3.2 \times 10^{7} \pm 4 \times 10^{6 a}$ & $54 \pm 3^{a}$ \\
\hline & $3 \mathrm{rd}$ & $0.21 \pm 0.02 \mathrm{~g}$ & $5.4 \times 10^{7} \pm 3 \times 10^{6} a$ & $53 \pm 5^{a}$ \\
\hline & 4 th & $0.17 \pm 0.0007^{\text {cde }}$ & $1.8 \times 10^{10} \pm 1 \times 10^{9 c}$ & $58 \pm 2^{a}$ \\
\hline & 5 th & $0.15 \pm 0.001^{\mathrm{cd}}$ & $3.1 \times 10^{10} \pm 3 \times 10^{9 d}$ & $56 \pm 2^{a}$ \\
\hline
\end{tabular}

The letters $(\mathrm{a}, \mathrm{b}, \mathrm{c}, \mathrm{d}, \mathrm{e}, \mathrm{f}$ and $\mathrm{g})$ represent honeys with significant differences by the Tukey test with a significance of $p=0.05$. Equal letters indicate that there are no significant differences.

With regard to the specific growth rate of $S$. cerevisiae, similar results were obtained in the fermentations with cells immobilized with $2 \%$ and $4 \%$ alginate. There were significant differences between the first fermentation (first use) and the other fermentations (reuse). This fact may be related to adaptation to the must and to the growing conditions in the alginate beads. The second and third fermentations using either $2 \%$ or $4 \%$ alginate were statistically similar. The same situation was found with the fourth and fifth fermentations; however, they showed to be also statistically similar with the fermentation with free cells.

The final biomass was identical in free cells and in the first three fermentations. In fermentations conducted with cells used four and cinq times, a significant increase in the final biomass was observed, with differences between the concentrations of alginate $2 \%$ and $4 \%$ (Table 3 and Figure 2). The final yield results (ethanol produced per gram of sugar consumed) showed to be statistically similar between all fermentations. The stationary phase of the fermentation carried out with free cells started at $72 \mathrm{~h}$; the first fermentation with immobilized cells started at $48 \mathrm{~h}$, and in the remaining fermentations at $24 \mathrm{~h}$. In the fermentations carried out with the alginate beads used for the second and third time, it was verified that the specific growth rate increased successively, and the stationary phase started immediately after $24 \mathrm{~h}$. However, in the fourth and fifth fermentations carried out with the reused alginate beads, the specific growth rate decreased compared to the two previous fermentations, reaching values similar to the growth of free cells. In these fermentations, the stationary phase also started after $48 \mathrm{~h}$. 
In Figure 3, the variation of reducing sugars versus the time of each fermentation effected either with $2 \%$ or $4 \%$ alginate beads is represented, including the fermentation with free cells. Regarding the sugars consumed, the values obtained in both tests (cells immobilized with $2 \%$ and $4 \%$ alginate) were similar. Figure 3 shows that in fermentations conducted with the first use of immobilized cells with $2 \%$ and $4 \%$ alginate, the consumption of sugars occurred until $96 \mathrm{~h}$. However, in the remaining fermentations, where the profile of sugar consumption was identical, its consumption occurred around $72 \mathrm{~h}$.
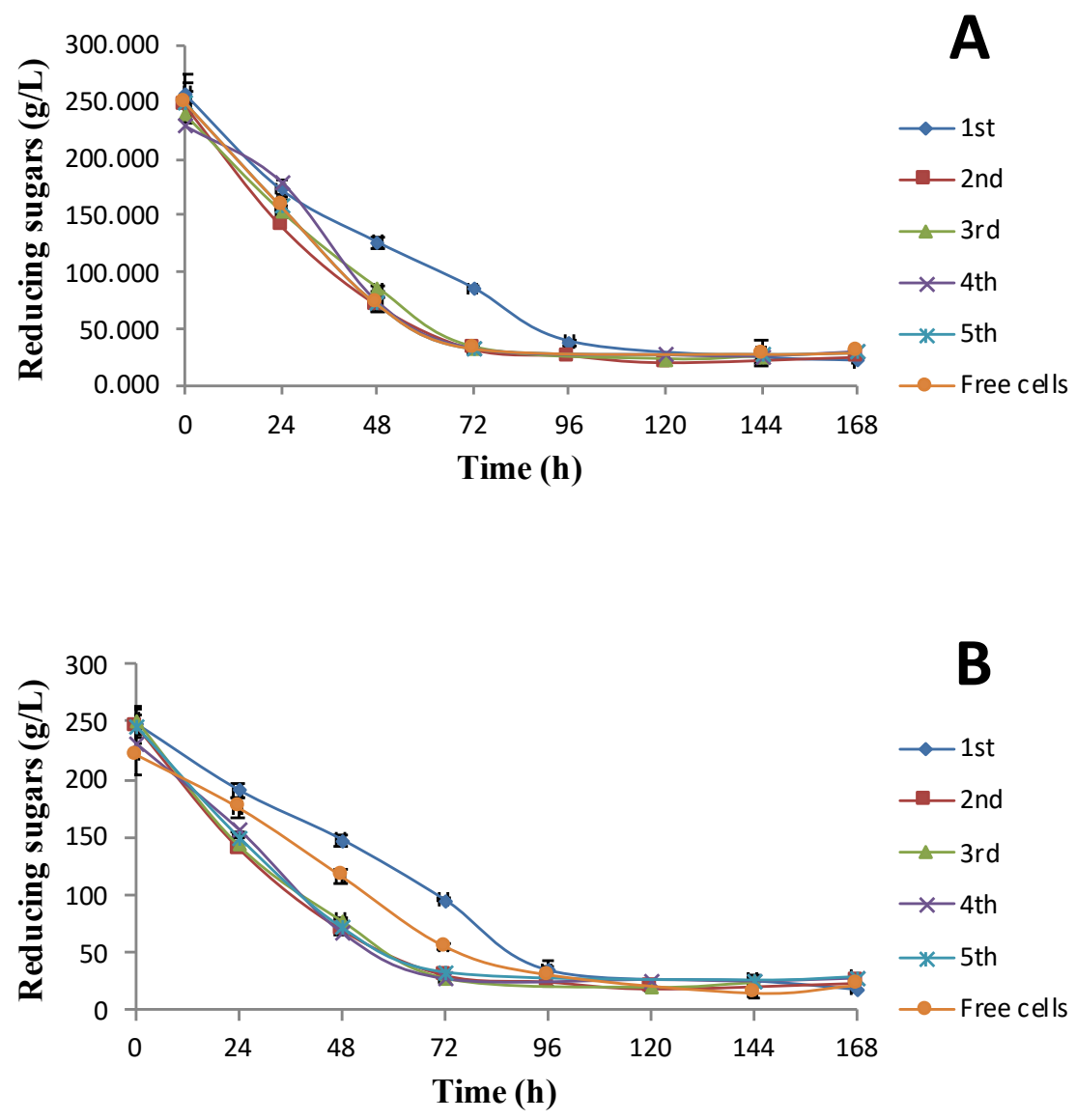

Figure 3. Variation of reducing sugars in fermentations with $S$. cerevisiae free cells and immobilized cells as a function of time: (A) — beads of $2 \%$ alginate reused in five fermentations; (B) — beads of $4 \%$ alginate reused in five fermentations.

The analysis of the results of this work suggests that fermentations with immobilized cells are more effective than those of free cells. However, it is necessary to perform the immobilization of the cells in new mechanically stable matrixes, since the immobilization with sodium alginate allowed the cells to leave the medium. In the case of mead production, this is an undesirable feature in clarifying the final product.

According to Duran [59], the immobilization increases the fermentative activity of yeast, promoting the adaptation of cells to the medium and eliminating the lag phase in successive fermentations. Bezbradica et al. [60], in beer production, observed an increase in the fermentation rate of $S$. cerevisiae cells immobilized in polyvinyl alcohol, obtaining 109 cells $/ \mathrm{mL}$, and consequently, a decrease in the duration of fermentation. Immobilization in polyvinyl alcohol showed high mechanical stability, as it endured thirty days of fermentation without altering cell activity and process yield.

\subsection{Physical-Chemical Characterization of the Final Product}

As noted in the previous point, the reuse of cells immobilized with $2 \%$ and $4 \%$ alginate did not affect the ethanol yield in the different fermentations. To evaluate the quality of 
the mead produced with free and immobilized cells after successive uses, the fermentation parameters were quantified, namely $\mathrm{pH}$, volatile acidity, total acidity, assimilable nitrogen, total $\mathrm{SO}_{2}$, alcohol content and final reducing sugars. Table 4 shows the results obtained from fermentations with free cells and immobilized cells with $2 \%$ and $4 \%$ alginate. The results showed that there were no significant differences in $\mathrm{pH}$ values between free cells and cells immobilized with $2 \%$ and $4 \%$ alginate. According to Sroka et al. [1], in the first days of wort fermentation, two main acids are produced, acetic acid and succinic acid, which are responsible for decreasing the $\mathrm{pH}$. The volatile acidity, expressed in $\mathrm{g} / \mathrm{L}$ of acetic acid, can give, above certain values, an unpleasant vinegar flavor or aroma, which makes the drink unfit for consumption, implying important economic losses for the producer. The formation of acetic acid can occur at any stage of alcoholic fermentation and influences the organoleptic quality of the mead.

Table 4. Physical-chemical analyses of mead.

\begin{tabular}{|c|c|c|c|c|c|c|c|c|}
\hline \multicolumn{2}{|c|}{ Fermentation } & \multirow{2}{*}{$\mathrm{pH}$} & \multirow{2}{*}{$\begin{array}{c}\begin{array}{c}\text { Volatile } \\
\text { Acidity }\end{array} \\
\begin{array}{c}\text { (g/L Acetic } \\
\text { Acid) }\end{array}\end{array}$} & \multirow{2}{*}{$\begin{array}{c}\text { Total Acidity } \\
\text { (g/L Tartaric } \\
\text { Acid) }\end{array}$} & \multirow{2}{*}{$\begin{array}{c}\begin{array}{c}\text { Assimilable } \\
\text { Nitrogen }\end{array} \\
(\mathrm{mg} / \mathrm{L})\end{array}$} & \multirow{2}{*}{$\begin{array}{c}\text { Total SO} \\
(\mathrm{mg} / \mathrm{L})\end{array}$} & \multirow{2}{*}{$\begin{array}{c}\text { Alcohol Content } \\
(\%)\end{array}$} & \multirow{2}{*}{$\begin{array}{c}\begin{array}{c}\text { Reducing } \\
\text { Sugars }\end{array} \\
(g / L)\end{array}$} \\
\hline Type & $\mathbf{N}^{\circ}$ & & & & & & & \\
\hline Free cells & Control & $3.35 \pm 0.13^{\mathrm{a}}$ & $0.78 \pm 0.03^{a}$ & $4.25 \pm 0.16^{\mathrm{ab}}$ & $32.67 \pm 4.04 \mathrm{ab}$ & $39.25 \pm 1.48^{c}$ & $11.33 \pm 0.12^{\mathrm{a}}$ & $24.02 \pm 0.61^{\mathrm{ab}}$ \\
\hline \multirow{5}{*}{$\begin{array}{l}\text { Immobilized cells } \\
\text { with } 2 \% \text { alginate }\end{array}$} & $1 \mathrm{st}$ & $3.63 \pm 0.10^{c}$ & $0.82 \pm 0.03^{a b}$ & $4.58 \pm 0.08^{b}$ & $21.00 \pm 0.01^{\mathrm{a}}$ & $28.16 \pm 0.01^{b}$ & $12.03 \pm 0.12^{b c}$ & $21.08 \pm 3.22^{a}$ \\
\hline & 2nd & $3.44 \pm 0.02 \mathrm{abc}$ & $1.08 \pm 0.01^{\mathrm{f}}$ & $5.36 \pm 0.27^{c}$ & $42.00 \pm 0.01 \mathrm{bc}$ & $30.72 \pm 0.01^{b}$ & $11.80 \pm 0.14^{\mathrm{abc}}$ & $24.97 \pm 0.55^{\mathrm{ab}}$ \\
\hline & $3 \mathrm{rd}$ & $3.51 \pm 0.16^{\mathrm{abc}}$ & $0.96 \pm 0.01^{\mathrm{de}}$ & $4.58 \pm 0.01^{\mathrm{b}}$ & $38.50 \pm 4.95^{\mathrm{bc}}$ & $30.72 \pm 0.01^{b}$ & $11.80 \pm 0.14^{\mathrm{abc}}$ & $24.77 \pm 3.36^{a b}$ \\
\hline & 4th & $3.51 \pm 0.02^{a b c}$ & $0.84 \pm 0.08^{a b c}$ & $4.05 \pm 0.32^{\mathrm{a}}$ & $42.00 \pm 0.01^{b c}$ & $30.72 \pm 3.62^{b}$ & $11.50 \pm 0.28^{a b}$ & $28.94 \pm 0.60^{b}$ \\
\hline & 5 th & $3.47 \pm 0.01 \mathrm{abc}$ & $0.93 \pm 0.04^{\text {bcde }}$ & $4.39 \pm 0.05^{\mathrm{ab}}$ & $73.50 \pm 4.95^{\mathrm{d}}$ & $16.64 \pm 1.81^{\mathrm{a}}$ & $11.55 \pm 0.50^{a b}$ & $29.34 \pm 1.43^{b}$ \\
\hline \multirow{5}{*}{$\begin{array}{l}\text { Immobilized cells } \\
\text { with } 4 \% \text { alginate }\end{array}$} & $1 \mathrm{st}$ & $3.61 \pm 0.01 \mathrm{bc}$ & $0.86 \pm 0.03 \mathrm{abcd}$ & $4.58 \pm 0.08^{b}$ & $23.33 \pm 4.04^{\mathrm{a}}$ & $28.16 \pm 0.01^{b}$ & $12.10 \pm 0.10^{c}$ & $19.46 \pm 2.40^{a}$ \\
\hline & 2nd & $3.37 \pm 0.10^{a b}$ & $1.02 \pm 0.01$ ef & $5.50 \pm 0.04^{c}$ & $46.67 \pm 4.04^{b c}$ & $30.72 \pm 2.56^{b}$ & $11.97 \pm 0.12^{b c}$ & $24.58 \pm 1.65^{a b}$ \\
\hline & $3 \mathrm{rd}$ & $3.46 \pm 0.04^{\mathrm{abc}}$ & $0.94 \pm 0.03$ cde & $4.10 \pm 0.04^{\mathrm{a}}$ & $42.00 \pm 0.01 \mathrm{bc}$ & $30.72 \pm 0.01^{b}$ & $11.90 \pm 0.01 \mathrm{bc}$ & $25.34 \pm 0.71^{\mathrm{ab}}$ \\
\hline & 4 th & $3.48 \pm 0.06^{\mathrm{abc}}$ & $0.92 \pm 0.03^{\text {bcde }}$ & $4.48 \pm 0.11^{\mathrm{ab}}$ & $49.00 \pm 7.00^{c}$ & $31.57 \pm 1.48^{b}$ & $11.70 \pm 0.01 \mathrm{abc}$ & $28.08 \pm 2.33^{b}$ \\
\hline & 5 th & $3.47 \pm 0.04^{\mathrm{abc}}$ & $0.94 \pm 0.03^{\text {cde }}$ & $4.20 \pm 0.15^{\mathrm{ab}}$ & $77.00 \pm 7.00^{d}$ & $16.21 \pm 1.48^{a}$ & $11.97 \pm 0.12^{b c}$ & $29.48 \pm 0.40^{b}$ \\
\hline
\end{tabular}

The letters (a, b, c, d, e and f) represent honeys with significant differences by the Tukey test with a significance of $p=0.05$. Equal letters indicate that there are no significant differences.

The lowest value was obtained in fermentation with free cells $(0.78 \mathrm{~g} / \mathrm{L})$ and the highest values, in the second use of immobilized cells both at $2 \%(1.08 \mathrm{~g} / \mathrm{L}$ acetic acid) and at $4 \%(1.02 \mathrm{~g} / \mathrm{L}$ acetic acid $)$ of alginate. Despite this, there were no significant differences in volatile acidity between the various fermentations. The values obtained in this work were higher than those recommended for $S$. cerevisiae when used in the white wine fermentations, which vary between 0.25 and $0.5 \mathrm{~g} / \mathrm{L}$ [61] but below the legal limit $(1.1 \mathrm{~g} / \mathrm{L})$ (EC Regulation $\mathrm{N}^{\circ} 1493 / 1999$, Annex VB-1b). Gomes [62], when producing mead at the pilot scale (20 L), obtained similar values. However, for the same strain (ICV D47) but with different wort formulations from the one used in this work, Pereira et al. [3] obtained lower volatile acid values in mead production. The results obtained may be associated with the composition of the honey must and the stress that the yeasts are subjected to during the fermentation of the must made from honey. Regarding total acidity, the same behavior was observed, that is, it was statistically identical when comparing fermentations with free cells with fermentations using immobilized cells, except for the second reuse, which presented a higher value. In other words, fermentation with immobilized cells with $2 \%$ alginate showed an acidity of $5.36 \mathrm{~g} / \mathrm{L}$ tartaric acid, and for fermentation with immobilized cells with $4 \%$ alginate, $5.50 \mathrm{~g} / \mathrm{L}$ tartaric acid. According to EC Regulation $\mathrm{N}^{\circ} 491 / 2009$, the total acidity in wines must be greater than or equal to $3.5 \mathrm{~g} / \mathrm{L}$ tartaric acid, thus, the values obtained for this parameter in the different fermentations are within the legislation. The assimilable nitrogen in the successive fermentations and for the different concentrations in alginate, varied between 21.0 and $49.0 \mathrm{mg} / \mathrm{L}$ and there were no significant differences between them, except for the fifth use, which presented values of $73.5 \mathrm{mg} / \mathrm{L}$ and $77.0 \mathrm{mg} / \mathrm{L}$ for 2 and $4 \%$ alginate, respectively. It should be noted that the differences observed may result from the fact that the initial nitrogen content of the honey from which the mead was produced does not have the same composition, as it was a second category honey. These results were in agreement 
with the observations of Mendes-Ferreira et al. [6]. These authors verified the presence of residual nitrogen when using two strains of $S$. cerevisiae and different concentrations of initial inoculum in the production of mead. The estimation of the residual nitrogen content may be the result of the quantification of nitrogen not assimilable by yeasts, in particular the proline amino acid. In fact, the formaldehyde method used has a recovery rate of only $23 \%$ for proline [63] and this amino acid represents 50 to $85 \%$ of the total nitrogen content of honey [64]. It should be noted that this amino acid is not used by $S$. cerevisiae. The absence of total $\mathrm{SO}_{2}$ in wine fermentations is uncommon, as yeasts produce this compound during fermentation which can be higher than $30 \mathrm{mg} / \mathrm{L}$ [65]. Analyzing Table 4, it appears that $\mathrm{SO}_{2}$ decreased in fermentations performed with immobilized cells, which may be due to the fact that immobilization facilitates the adaptation of cells and reduces the accumulation of inhibitory substances, that is, reducing the conditions of stress.

\section{Conclusions}

The production of mead was made possible through the alcoholic fermentation of honey must using Saccharomyces cerevisiae immobilized in beads with $2 \%$ and $4 \%$ concentrations of alginate. In the fermentation conducted with the first use of immobilized cells with $2 \%$ and $4 \%$ alginate, the consumption of sugars finished at $96 \mathrm{~h}$, while in the remaining fermentations, where the profile of sugar consumption was identical, the consumption ends at $72 \mathrm{~h}$. The immobilization of cells did not significantly influence some process parameters, such as the yield of the consumed sugars/ethanol, the alcohol content, the $\mathrm{pH}$ and the total acidity. Regarding volatile acidity, there was a slight increase. There was also a decrease in the production of $\mathrm{SO}_{2}$. The alginate concentration $(2 \%$ and $4 \%) \operatorname{did}$ not significantly influence either the parameters used to monitor the fermentation process nor the characteristics of the mead. As for the mechanical stability of the beads, it was found that the $4 \%$ alginate was mechanically more stable, allowing a greater number of reuses, making the process more economical. However, the cells' specific growth rate in the fourth and fifth fermentations carried out with the reused alginate beads reached values similar to the growth of free cells. Future work using new cell immobilization matrixes will be carried out since it allows to increase productivity, have a high number of cells in the bioreactor, reuse biomass in consecutive batch processes, have greater tolerance to inhibitory substances and eliminate contamination, as well as to reduce the formation of by-products, costs with the process, costs with the centrifugation, filtration and purification of the final product.

Author Contributions: M.L.S.-D.--investigation, data treatment and original draft preparation; V.B.P.-writing the final article and editing; L.G.D.- conceptualization, methodology and supervision; L.M.E.- project administration, funding acquisition and final revision. All authors have read and agreed to the published version of the manuscript.

Funding: This research received no external funding.

Institutional Review Board Statement: Not applicable.

Informed Consent Statement: Not applicable.

Data Availability Statement: Not applicable.

Acknowledgments: The authors are grateful to the Foundation for Science and Technology (FCT, Portugal) and FEDER under Programme PT2020 for financial support to CIMO (UID/AGR/00690/2019).

Conflicts of Interest: The authors declare no conflict of interest.

\section{References}

1. Sroka, P.; Tuszyński, T. Changes in organic acid contents during mead wort fermentation. Food Chem. 2007, 104, 1250-1257. [CrossRef]

2. Navrátil, M.; Sturdík, E.; Gemeiner, P. Batch and continuous mead production with pectate immobilised, ethanol-tolerant yeast. Biotechnol. Lett. 2001, 23, 977-982. [CrossRef] 
3. Pereira, A.; Mendes-Ferreira, A.; Oliveira, J.; Estevinho, L.; Mendes-Faia, A. High-cell-density fermentation of Saccharomyces cerevisiae for the optimisation of mead production. Food Microbiol. 2013, 33, 114-123. [CrossRef] [PubMed]

4. McConnell, D.S.; Schramm, K.D. Mead success: Ingredients, processes and techniques. Zymurgy Spring 1995, 4, 33-39.

5. Pereira, A.P.; Dias, T.; Andrade, J.; Ramalhosa, E.; Estevinho, L.M. Mead production: Selection and characterization assays of Saccharomyces cerevisiae strains. Food Chem. Toxicol. 2009, 47, 2057-2063. [CrossRef]

6. Mendes-Ferreira, A.; Cosme, F.; Barbosa, C.; Falco, V.; Inês, A.; Mendes-Faia, A. Optimization of honey-must preparation ad alcoholic fermentation by Saccharomyces cerevisiae for mead production. Int. J. Food Microbiol. 2010, 144, 193-198. [CrossRef]

7. Roldán, A.; Van Muiswinkel, G.; Lasanta, C.; Palacios, V.; Caro, I. Influence of pollen addition on mead elaboration: Physicochemical and sensory characteristics. Food Chem. 2011, 126, 574-582. [CrossRef]

8. Ukpabi, U.J. Quality evaluation of meads produced with cassava (Manihot esculenta) floral honey under farm conditions in Nigeria. Trop. Subtrop. Agroecosyst. 2006, 6, 37-41.

9. Wintersteen, C.L.; Andrae, L.M.; Engeseth, N.J. Effect of Heat Treatment on Antioxidant Capacity and Flavor Volatiles of Mead. J. Food Sci. 2005, 70, C119-C126. [CrossRef]

10. Ivorra, C.; Pérez-Ortín, J.E.; Del Olmo, M. An inverse correlation between stress resistance and stuck fermentations in wine yeasts. A molecular study. Biotechnol. Bioeng. 1999, 64, 698-708. [CrossRef]

11. Casellas, G.B. Effect of Low Temperature Fermentation and Nitrogen Content on Wine Yeast Metabolism. Ph.D. Thesis, Universitat Rovira i Virgili, Spain, France, 2005.

12. Champagne, C.P.; Gaudy, C.; Poncelet, D.; Neufeld, R.J. Lactococcus lactis release from calcium alginate beads. Appl. Environ. Microbiol. 1992, 58, 1429-1434. [CrossRef]

13. Genisheva, Z.; Macedo, S.; Mussatto, S.I.; Teixeira, J.A.; Oliveira, J.M. Production of White Wine by Sacchomyces cerevisiae immobilized on grape pomace. J. Inst. Brew. 2012, 118, 163-173. [CrossRef]

14. Coelho, T.C. Avaliação das Condições de Imobilização de Células de Candida Guilliermondii FTI 20037 em Bucha Vegetal (Luffa Cylindrica) Visando a Produção de Xilitol. Master's Thesis, Universidade de São Paulo, São Paulo, Brazil, 2007.

15. Covizzi, L.G.; Giese, E.C.; Gomes, E.; Dekker, R.F.H.; Da Silva, R. Imobilização de células microbianas e suas aplicações biotecnológicas. Semin. Ciências Exatas Tecnológicas 2007, 28, 143. [CrossRef]

16. Inal, M.; Yiğitoğlu, M. Production of bioethanol by immobilized Saccharomyces Cerevisiae onto modified sodium alginate gel. J. Chem. Technol. Biotechnol. 2011, 86, 1548-1554. [CrossRef]

17. Hernández, R.M.; Orive, G.; Murua, A.; Pedraz, J.L. Microcapsules and microcarriers for in situ cell delivery. Adv. Drug Deliv. Rev. 2010, 62, 711-730. [CrossRef]

18. Najafpour, G.; Younesi, H.; Ismail, K.S.K. Ethanol fermentation in an immobilized cell reactor using Saccharomyces cerevisiae. Bioresour. Technol. 2004, 92, 251-260. [CrossRef]

19. Liouni, M.; Drichoutis, P.; Nerantzis, E.T. Studies of the mechanical properties and the fermentation behavior of double layer alginate-chitosan beads, using Saccharomyces cerevisiae entrapped cells. World J. Microbiol. Biotechnol. 2007, 24, 281-288. [CrossRef]

20. Carvalho, W.; Canilha, L.; Silva, S.S. Uso de Biocatalizadores Imobilizados: Uma alternativa para a condução de bioprocessos. Rev. Anal. 2006, 23, 60-70.

21. Oliveira, M.A. Produção de Cerveja de Baixo teor Alcoólico Utilizando Leveduras Imobilizadas em Biopolímero. Master's Thesis, Universidade Tiradentes, Aracaju, Brazil, 2011.

22. Divies, C.; Cachon, R. Wine Production by immobilized cell systems. In Applications of Cell Immobilisation Biotechnology, Focus on Biotechnology, 1st ed.; Nedović, V., Willaert, R., Eds.; Springer: Dordrecht, The Netherlands, 2005; Volume 8B, pp. $285-293$.

23. Wang, S.; Song, C.; Chen, G.; Guo, T.; Liu, J.; Zhang, B.; Takeuchi, S. Characteristics and biodegradation properties of poly(3hydroxybutyrate-co-3-hydroxyvalerate)/organophilic montmorillonite (PHBV/OMMT) nanocomposite. Polym. Degrad. Stab. 2005, 87, 69-76. [CrossRef]

24. Nikolić, S.; Mojović, L.; Rakin, M.; Pejn, D.; Nedović, V. Effect of different fermentation parameters on bioethanol production from corn meal hydrolyzates by free and immobilized cells of Saccharomyces cerevisiae var. ellipsoideus. J. Chem. Technol. Biotechnol. 2008, 84, 497-503. [CrossRef]

25. Vilela, A.; Schuller, D.; Mendes-Faia, A.; Côrte-Real, M. Reduction of volatile acidity of acidic wines by immobilized Saccharomyces cerevisiae cells. Appl. Microbiol. Biotechnol. 2013, 97, 4991-5000. [CrossRef]

26. Ciani, M.; Ferraro, L. Enhanced Glycerol Content in Wines Made with Immobilized Candida stellata Cells. Appl. Environ. Microbiol. 1996, 62, 128-132. [CrossRef]

27. Kostov, G.; Angelov, M.; Mihaylov, I.; Poncelet, D. Mechanical properties of Ca-alginate beads for ethanol fermentation with immobilized yeast. Rev. Genie Ind. 2010, 5, 25-35.

28. Drichoutis, P.; Nerantzes, E.T.; Liouni, M. Continuous production of wine in a tower fermentor using entrapped yeast cells in double layer alginate-chitosan beads. e-J. Sci. Technol. 2007, 6, 51-60.

29. Harmonized Methods of the International Honey Commission, International Honey Commission, IHC Methods. 2009. Available online: https:/ / www.ihc-platform.net/ihcmethods2009.pdf (accessed on 1 November 2020).

30. Sancho, M.T.; Muniategui, S.; Sánchez, P.; Huidobro, J.F.; Simal, J. Mieles del Pais Vasco, XI: Evaluación de los distintos tipos de cenizas. An. Bromatol. 1991, 4, 311-324.

31. Bogdanov, S.; Martin, P.; Lüllmann, C. Harmonised methods of the European Honey Commision. Apidologie 1997, 28 , 1-59. 
32. Anonymous. Métodos oficiales de análisis para la miel. Orden de 12 de Junio de 1986 de la Presidência del Gobierno, “Boletín Oficial del Estado" no 145 de 18 de Junio de XXIII-Edulcorantes naturales y derivados. 1986. Available online: https: / / www.boe.es/eli/es/o/1986/06/12/(3) (accessed on 26 February 2020).

33. Bianchi, E.M. Control de Calidad de la Miel y la Cera; Organización de las Naciones Unidas para la Agriculture y Alimentación (FAO): Rome, Italy, 1990.

34. Louveaux, J.; Maurizio, A.; Vorwohl, G. Methods of melissopalynology. Bee World 1978, 59, 139-157. [CrossRef]

35. Miller, G.L. Use of Dinitrosalicylic Acid Reagent for Determination of Reducing Sugar. Anal. Chem. 1959, 31, 426-428. [CrossRef]

36. International Organisation of Vine and Wine. Compendium of International Methods of Wine and Must Analysis, Volume 1; OIV: Paris, France, 2021.

37. Aerny, J. Composés azotes des moûts et des vins. Revue Suisse de Viticulture, Arboriculture. Horticulture 1996, $28,161-165$.

38. International Organisation of Vine and Wine. Compendium of International Methods of Wine and Must Analysis, Volume 2; OIV: Paris, France, 2021.

39. Curvelo-Garcia, A.S. Controlo de Qualidade Dos vinhos. Química Enológica e Métodos Analíticos; Instituto da Vinha e do Vinho: Lisboa, Portugal, 1998.

40. Göksungur, Y.; Zorlu, N. Production of Ethanol from Beet Molasses by Ca- Alginate Immobilized Yeast Cells in a Packed-Bed Bioreactor. Turk. J. Biol. 2001, 25, 265-275.

41. Maia, M.; Russo-Almeida, P.; Pereira, J.O. Caracterização do Espectro Polínico dos Méis do Alentejo (Portugal). Silva Lusit. 2005, 13, 95-103.

42. Bogdanov, S.; Ruoh, K.; Oddo, L.P. Physico-chemical methods for the characterization of unifloral honeys: A review. Apidologie 2004, 35, S4-S17. [CrossRef]

43. De Rodríguez, G.O.; De Ferrer, B.S.; Ferrer, A.; Rodríguez, B. Characterization of honey produced in Venezuela. Food Chem. 2004, 84, 499-502. [CrossRef]

44. Vargas, T. Avaliação da Qualidade do mel Produzido na Região dos Campos Gerais do Paraná. Master's Thesis, Universidade Estadual de Ponta Grossa, Ponta Grossa, Brazil, 2006.

45. Al, M.L.; Daniel, D.; Moise, A.R.; Bobis, O.; Laslo, L.; Bogdanov, S. Physico-chemical and bioactive properties of different floral origin honeys from Romania. Food Chem. 2009, 112, 863-867. [CrossRef]

46. Acquarone, C.; Buera, P.; Elizalde, B. Pattern of $\mathrm{pH}$ and electrical conductivity upon honey dilution as a complementary tool for discriminating geographical origin of honeys. Food Chem. 2007, 101, 695-703. [CrossRef]

47. Küçük, M.; Kolaylı, S.; Karaoğlu, Ş.; Ulusoy, E.; Baltacı, C.; Candan, F. Biological activities and chemical composition of three honeys of different types from Anatolia. Food Chem. 2007, 100, 526-534. [CrossRef]

48. Evangelista-Rodrigues, A.; Silva, E.M.S.d.; Beserra, E.M.F.; Rodrigues, M.L. Análise físico-química dos méis das abelhas Apis mellifera e Melipona scutellaris produzidos em regiões distintas no Estado da Paraíba. Ciência Rural 2005, 35, $1166-1171$. [CrossRef]

49. Abu-Tarboush, H.M.; Al-Kahtani, H.A.; El-Sarrage, M.S. Foral-type identication and quality evaluation of some honey types. Food Chem. 1993, 26, 17-33.

50. Iurlina, M.O.; Fritz, R. Characterization of microorganisms in Argentinean honeys from different sources. Int. J. Food Microbiol. 2005, 105, 297-304. [CrossRef]

51. Souza, D.C.; Bazlen, K. Análises Preliminares de Características Físico-Químicas de Méis de Tiúba (Melipona compressipes) do Piauí; XII Congresso Brasileiro de Apicultura: Salvador, BA, USA, 1998.

52. Aroucha, E.M.M.; Oliveira, A.J.F.; Nunes, G.H.S.; Maracajá, P.B. Qualidade do mel de abelha produzidos pelos Incubados da iagram e comercializado no Município de Mossoró/RN. Caatinga Mossoró 2004, 21, 211-217.

53. Valbuena, A.O. Contribución a la Denominación de Origen de la Miel de la Alcarria. Ph.D. Thesis, Facultad de Ciencias Biológicas de la Universidad Complutense de Madrid, Spain, France, 1992.

54. Fallico, B.; Arena, E.; Verzera, A.; Zappalà, M. The European Food Legislation and its impact on honey sector. Accredit. Qual. Assur. 2006, 11, 49-54. [CrossRef]

55. Carillo Magana, F.A. Meliponicultura: El Mundo de las Abejas Nativas de Yucatán; Blackwell Publishing: Mérida, México, 1998.

56. Azeredo, L.C.; Azeredo, M.; De Souza, S.; Dutra, V. Protein contents and physicochemical properties in honey samples of Apis mellifera of different floral origins. Food Chem. 2003, 80, 249-254. [CrossRef]

57. Smidsrød, O.; Skjåk-Bræk, G. Alginate as immobilization matrix for cells. Trends Biotechnol. 1990, 8, 71-78. [CrossRef]

58. Mendes-Faia, A.; Côrte-Real, M. Redução da acidez volátil de vinhos por células de Saccharomyces cerevisiae imobilizadas em esferas de alginato-quitosano. Enologia 2012, 38-42.

59. Duran, P.M.; Baley, J.E. Effects of immmobilization on growth, fermentations properties and macromolecular composition of S. cerevisiae attached to gelatin. Biotecnol. Bioeng. 1986, 28, 73-87. [CrossRef]

60. Bezbradica, D.; Obradovic, B.; Leskosek-Cukalovic, I.; Bugarski, B.; Nedovic, V. Immobilization of yeast cells in PVA particles for beer fermentation. Process. Biochem. 2007, 42, 1348-1351. [CrossRef]

61. Nikolaou, E.; Soufleros, E.H.; Bouloumpasi, E.; Tzanetakis, N. Selection of indigenous Saccharomyces cerevisiae strains according to their oenological characteristics and vinification results. Food Microbiol. 2006, 23, 205-211. [CrossRef]

62. Gomes, T. Produção de Hidromel: Efeitos das Condições de Fermentação. Master's Thesis, Instituto Politécnico de Bragança, Bragança, Portugal, 2010. 
63. Filipe-Ribeiro, L.; Mendes-Faia, A. Validation and comparison of analytical methods used to evaluate the nitrogen status of grape juice. Food Chem. 2007, 100, 1272-1277. [CrossRef]

64. Anklam, E. A review of the analytical methods to determine the geographical and botanical origin of honey. Food Chem. 1998, 63, 549-562. [CrossRef]

65. Ribéreau-Gayon, P.; Dubourdieu, D.; Donèche, B.; Lonvaud, A. Handbook of Enology. Handb. Enol. 2005, 1. [CrossRef] 